\title{
PENGARUH METODE HAFALAN AL-QUR'AN TERHADAP TINGKAT KECERDASAN SPIRITUAL SANTRI DI PONDOK PESANTREN DAARUL-ANBA
}

\author{
Yuni Hidayati \\ STAINU Tasikmalaya \\ unida85@yahoo.com
}

\begin{abstract}
This study aims to determine how the influence of the Al-Qur'an memorization method on the level of spiritual intelligence of students in Daarul Anba Islamic boarding school, the approach used in this study is a quantitative approach, while the descriptive correlational research method. The results of this study are: 1) Description of the Al-Qur'an Memorization Method is very good. 2) Santri Spiritual Intelligence Level in Daarul-Anba Islamic Boarding School is in the Very Good category. 3) Based on the results of calculations that the significant correlation coefficient is indicated by the tcount $=1.797$ greater than ttable $=0.3008$ so that Ho is rejected and Ha is accepted, ie there is a significant correlation or relationship between the Al-Qur'an Memorization Method on the Level of Spiritual Intelligence Santri in Daarul-Anba Islamic Boarding School. The results also showed that the determination value of 7.29\% was determined by the Qur'an recitation method which was quite good. And the remaining $92.71 \%$ is influenced by other factors not examined by researchers.
\end{abstract}

Keywords: Al-Qur'an Memorization Method, Level of Spiritual Intelligence

\section{Abstrak}

Penelitian ini bertujuan untuk mengetahui bagaimana pengaruh metode hafalan Al-Qur'an terhadap tingkatkecerdasan spiritual santri di pondok pesantren Daarul Anba, Pendekatan yang digunakan dalam 
penelitian ini adalah pendekatan kuantitatif, sedangkan metode penelitiannya korelasional deskriptif. Hasil dari penelitian ini yaitu : 1) Deskripsi Metode Hafalan Al-Qur'an sangat baik. 2) Tingkat Kecerdasan Spiritual Santri di Pondok Pesantren Daarul-Anba masuk pada kategori Sangat Baik. 3) Berdasarkan hasil perhitungan bahwa koefisien korelasi signifikan ditunjukan dengan nilai thitung $=1,797$ lebih besar dari ttabel $=0,3008$ sehingga Ho di tolak dan Ha diterima, yaitu terdapat korelasi atau hubungan yang signifikan antara Metode Hafalan Al-Qur'an terhadap Tingkat Kecerdasan Spiritual Santri di Pondok Pesantren Daarul-Anba. Hasil penelitian juga menunjukan bahwa nilai determinasi sebesar 7,29\% ditentukan oleh Metode hafalan Al-Qur'an yang cukup baik. Dan sisanya sebesar 92,71\% di pengaruhi oleh faktor-faktor yang lain yang tidak diteliti oleh peneliti.

Kata Kunci: Metode Hafalan Al-Qur'an, Tingkat Kecerdasan Spiritual

\section{PENDAHULUAN}

Pondok pesantren merupakan sarana untuk menambah wawasan para pelajar yang identik di juluki santri yang bersifat duniawi maupun ukhrowi, karena bahan yang sering dikaji di pondok pesantren cenderung tentang bagaimana hubungan manusia dengan mausia (hablumminannaas) dan bagaimana hubungan manusia dengan Allah Swt (hablumminalloh).

Pondok pesantren merupakan lembaga non formal namun meskipun demikian eksistensi pondok pesantren di Indonesia khususnya di Tasikmalaya sangat berkembang pesat. Sehingga Tasikmalaya dijuluki sebagai kota santri. Dengan demikian sebutan pondok pesantren atau pondok menjadi sangat populer, masyarakat sering mengartikan istilah pondok identik dengan pesantren itu sendiri.

Pondok pesantren sebagai lembaga pendidikan tradisional yang berkomitmen sebagai lembaga pendidikan tafaqquh fiddin tidak diragukan lagi dapat memberikan peran yang sangat penting dalam meningkatkan kualitas pendidikan para santri, dengan indikator selalu memiliki kemantapan aqidah dan kedalaman spiritual, keagungan 
akhlak dan moral, keluasan ilmu pengetahuan dan siap berkompetisi dalam era global dengan kesiapan hidup pada masa sekarang ataupun masa yang akan datang.

Pesantren menurut Mujamil qomar merupakan hasil usaha mandiri kyai yang dibantu santri dan masyarakat sehingga memiliki bentuk. Selama ini belum pernah terjadi dan barangkali cukup sulit terjadi penyeragaman pesantren dalam skala nasional, karena setiap pesantren memiliki ciri khusus akibat perbedaan sosial budaya maupun sosial grafis yang mengelilinginya. Variasi pondok pesantren tersebut perlu di tingkatkan secara kategorial. ${ }^{1}$ Pendidikan pesantren memiliki ciri khas tersendiri, tetapi di dalamnya terdapat esensi yang sama dengan pendidikan islam pada umumnya. Adapun pendidikan pesantren mencakup cici-ciri pesantren yakni; 1) Pondok sebagai asrama santri. 2). Masjid sebagai sentral peribadatan. 3). Pengajian kitab kuning atau kitab-kitab klasik. 4). Santri sebagai peserta didik. 5). Kyai sebagai pimpinan dan pengasuh.

Ketika para santri belajar di pondok pesantren tentunya banyak sekali ilmu yang dapat diambil, begitupun ilmu-ilmu yang sering diajarkan oleh dewan kyai maupun oleh para asatidz. Oleh karena itu kecerdasan para santripun harus dilatih. Terutama kecerdasan Spiritual, kecerdasan ini yang sangat penting dimiliki oleh setiap manusia dalam menjalani kehidupannya di muka bumi ini sebagai makhluk Tuhan

Kecerdasan Spiritual merupakan temuan mutakhir secara ilmiah yang pertama kali digagas oleh Dannah Zohar dan Ian Marshall, masing-masing dari Hardvard University dan Oxford University melalui serangkaian penelitian yang sangat komprehensif. Mereka mendefinisikan kecerdasan spiritual sebagai kecerdasan untuk menghadapi persoalan makna atau value, yaitu kecerdasan untuk menempatkan prilaku dan hidup dalam konteks makna yang lebih luas dan kaya, kecerdasan untuk menilai bahwa tindakan atau jalan hidup seseorang lebih bermakna dibandingkan dengan yang lain. ${ }^{2}$ 
Menurut Kamus Besar Bahasa Indonesia (KBBI) cerdas ialah sempurna akal budi seorang manusia untuk berfikir, mengerti,tajam fikiran dan sempurna pertumbuhan tubuhnya.

Artinya :"Diriwayatkan dari Syaddad bin Aus Rasulullah Saw bersabda "Orang yang cerdas adalah orang yang mampu menaklukkan (hawa) nafsunya dan beramal demi hari kematiannya. Sedangkan orang yang lemah (dungu) adalah orang yang mengikuti keinginan (hawa) nafsunya lalu ia hanya berharap-harap kepada Allah Swt." (HR At-Tirmidzi, ibnu majah dan Ahmad At-Tirmidzi berkata" hadits ini hasan, namun didhaifkan Al-Albani ). ${ }^{3}$

Dari permasalahan di atas, diperlukan pola pembelajaran yang tepat, salah satunya yaitu dengan membelajarkan Al-Qur'an kepada para santri sejak dini, karena "Sebaik-baik manusia ialah orang yang mempelajari Al-Qur'an dan mengamalkannya" (Al-Hadist). Al-Qur'an adalah kalam Allah SWT yang diturunkan kepada Nabi Muhammad SAW (yang merupakan Mukjizat) melalui perantara malaikat Jibril untuk disampaikan kepada umat manusia sebagai pedoman hidup, agar mendapatkan petunjuk untuk kebahagiaan dunia dan akhirat. ${ }^{4}$

Oleh karena itu metode hafalan Al-Qur'an sangat berpengaruh positif terhadap tingkat kecerdasan spiritual seseorang. Salah satu cara agar seseorang hafal terhadap ilmu yang sudah dikajinya yaitu dengan cara mudzakarah artinya mengulang-ngulang atau mengingat suatu ilmu yang sudah didapatkan oleh seseorang agar tidak lupa akan suatu ilmu yang sudah dikaji tersebut. Dengan demikian para pengasuh pondok pesantren Daarul-Anba berusaha sekuat tenaga membimbing, mengelola dan mendidik santrinya dengan pola asuh dan pendidikan serta pengajaran yang didesain secara efektif, dengan manajemen yang modern, yang nantinya akan memberikan efek atau solusi terhadap masalah tersebut.

2 Agustian Ary Ginanjar, Rahasia Sukses Membangun Kecerdasan Emosi dan Spiritual (ESQ),(Jakarta:Arga.2001), h.57

3 Raghib As-Sirjani dan Abdurrahman Abdul Khalik,(2013), Cara Cerdas Menghafal A-Qur'an, PT.AQWAM MEDIA PROFETIKA: Solo Hal.64 4 Mahfud Rois, Al-Islam, Pendidikan Agama Islam, (Jakarta:Erlangga,2011), h.107 
Dalam penelitian ini, penulis akan mengupas beberapa permasalahan yang dijadikan rumusan masalah. Bagaimana metode hafalan Al-Qur'an santri di pondok pesantren Daarul-Anba? Bagaimana cara mengukur tingkat kecerdasan spiritual santri di pondok pesantren Daarul-Anba? Seberapa besar pengaruh metode hafalan Al-qur'an terhadap tingkat kecerdasan Spiritual santri di pondok pesantren Daarul-Anba?

\section{METODE PENELITIAN}

Metode penelitian yang digunakan adalah metode kuantitatif yaitu : metode yang berlandaskan pada positivisme, digunakan untuk meneliti pada populasi atau sampel tertentu, teknik pengambilan sampel pada umumnya dilakukan secara random, pengumpulan data menggunakan instrument penelitian analisis data bersifat kuantitatif atau statistik dengan tujuan untuk menguji hipotesis yang telah ditetapkan. $^{5}$

Adapun yang akan dijadikan populasi dalam penelitian ini adalah seluruh Santri putri pondok pesantren Daarul-Anba Bantargedang sebanyak 73 orang. Pengambilan sampel diambil secara simple random sampling yaitu pengambilan sampel dari anggota populasi yang dilakuan secara acak tanpa memperhatikan strata yang ada dalam populasi itu. Cara demikian dilakuan bila anggota populasi dianggap homogen.

Untuk menentukan sampel yang diambil dengan menggunakan rumus yang ditemukan oleh Jalaludin Rahmat (1993 : 83) sebagai berikut:

$$
\begin{aligned}
& n=\frac{N}{N(0,1)^{2}+1} \\
& \quad \text { Dimana : } \\
& \mathrm{n}=\text { Jumlah Sampel } \\
& \mathrm{N}=\text { Jumlah Populasi } \\
& \quad 0,1=\text { Batas Ketelitian yang digunakan }(10 \%)
\end{aligned}
$$

5 Sugiyono Metode Penelitian Pendidikan...hlm.14 
Dari populasi 73 orang santri, maka dapat diambil sampel yaitu :

$$
n=\frac{N}{N(0,1)^{2}+1}
$$

$$
n=\frac{73}{73(0,1)^{2}+1}
$$

$\mathrm{n}=43$

\section{a.Uji Validitas}

Pengujian validitas alat ukur dalam penelitian ini menggunakan pendekatan korelasi Product Moment Pearson Correlation, dengan rumus:

$$
\operatorname{rxy}=\frac{n \sum x_{1} y_{1}-\left(\sum x_{1}\right)\left(\sum y_{1}\right)}{\sqrt{\left\{n \sum x_{1^{2}}-\left(\sum x_{1}\right)^{2}\right\}\left\{n \sum y_{1^{2}}-\left(\sum y_{1}\right)^{2}\right\}}}
$$

Dalam hal ini :

$$
\begin{array}{rlrl}
\text { rxy } & = & \text { Koefisien Korelasi antara variable X dengan } \mathrm{Y} \\
\sum \mathrm{x}= & & \text { Jumlah Skor item } \\
\sum \mathrm{y}= & & \text { Jumlah Skor item } \\
\mathrm{x} & = & (\mathrm{x} 1-\overline{\mathrm{x}}) \\
\mathrm{y}= & (\mathrm{y} 1-\bar{y})
\end{array}
$$

Jika koefisien korelasinya lebih besar daripada 0,30 maka butir angket dianggap valid; sebaliknya, jika kurang daripada 0,30 , maka dianggap tidak valid.

b. Uji Reliabilitas

Untuk menguji reliabilitas alat ukur, terlebih dahulu dicari harga korelasi secara keseluruhan dengan mengunakan korelasi Product Moment. Adapun rumus yang digunakan;

$$
\begin{aligned}
& \mathrm{S} 12=\frac{\sum X_{1^{2}}}{n}-\frac{\left(X_{1}\right)^{2}}{n} \\
& \mathrm{~S} 12=\frac{\sum K_{1^{2}}}{n}-\frac{(\mathrm{JKS})^{2}}{n^{2}}
\end{aligned}
$$

Dalam hal ini:

$\mathrm{JKi}=\quad$ Jumlah kuadrat dari seluruh skor item

$\mathrm{JKs}=$ Penjumlahan dari hasil kuadrat subjek 
$\mathrm{n}=$ Jumlah responden

Mencari koefisien reliabilitas dengan menggunakan rumus Alfa Croanbach;

$\mathrm{r} 1=\left\{\frac{k}{5-1}\right\}\left\{\frac{1-\sum S_{1^{2}}}{S_{1^{2}}}\right\}$

Dalam hal ini :

r1 $=$ Koefisien korelasi

$\sum \mathrm{S} 12=$ Jumlah varian item

$\mathrm{K} \quad=$ Banyaknya butir pertanyaan

$\mathrm{S} 12=$ Varian total

Hasil perhitungan uji reabilitas dengan menggunakan bantuan program SPSS IBM versi 21.0

Teknik pengumpulan datanya menggunakan angket, observasi dan dokumentasi. Sedangkan tekhnik analisis data menggunakan deskriptif dan uji hipotesis.

\section{HASIL DAN PEMBAHASAN}

\section{Metode Hafalan Al-Qur'an}

Data mengenai metode hafalan Al-Qur'an yang merupakan variabel $\mathrm{X}$ (independen) merupakan data yang diperoeh langsung dari pengisian instrument penelitiian yang berbentuk skala lkert dengan 5 pilihan jawaban yaitu sangat setuju diberi skor 5 , Setuju diberi skor 4, Ragu-ragu di beri skor 3, Tidak Setuju di beri skor 2, Sangat Tidak Setuju diberi skor 1. Instrument tersebut disebarkan kepada 43 orang santri putri di pondok pesantren Daarul-Anba sebagai responden dengan 18 item pertayaan.

Untuk lebih jelasnya deskripsi dari penelitian mengenai metode hafalan Al-Qur'an dapat dilihat dari tabel berikut.

\section{Tabel 4.1}

Rekapitulasi Tanggapan Responden Mengenai Variabel X

\begin{tabular}{|c|c|c|c|c|c|c|c|c|c|c|c|c|}
\hline \multicolumn{13}{|c|}{ Rekapitulasi Tanggapan Responden Metode Hafalan Al-Qur'an } \\
\hline \multirow{2}{*}{ Resp } & \multicolumn{5}{|c|}{ Jawaban } & \multicolumn{5}{|c|}{ Penskoran } & \multirow{2}{*}{ Total } & \multirow{2}{*}{$\begin{array}{c}\text { Jumlah } \\
\text { Soal }\end{array}$} \\
\hline & SS & $\mathrm{S}$ & $\mathbf{R}$ & TS & STS & 5 & 4 & 3 & 2 & 1 & & \\
\hline 1 & 17 & 1 & 0 & 0 & 0 & 85 & 4 & 0 & 0 & 0 & 89 & 18 \\
\hline
\end{tabular}


Thorigotuna | Jurnal Pendidikan Islam

\begin{tabular}{|c|c|c|c|c|c|c|c|c|c|c|c|c|}
\hline 2 & 12 & 6 & 0 & 0 & 0 & 60 & 24 & 0 & 0 & 0 & 84 & 18 \\
\hline 3 & 6 & 12 & 0 & 0 & 0 & 30 & 48 & 0 & 0 & 0 & 78 & 18 \\
\hline 4 & 11 & 5 & 2 & 0 & 0 & 55 & 20 & 6 & 0 & 0 & 81 & 18 \\
\hline 5 & 18 & 0 & 0 & 0 & 0 & 90 & 0 & 0 & 0 & 0 & 90 & 18 \\
\hline 6 & 16 & 2 & 0 & 0 & 0 & 80 & 8 & 0 & 0 & 0 & 88 & 18 \\
\hline 7 & 13 & 5 & 0 & 0 & 0 & 65 & 20 & 0 & 0 & 0 & 85 & 18 \\
\hline 8 & 12 & 6 & 0 & 0 & 0 & 60 & 24 & 0 & 0 & 0 & 84 & 18 \\
\hline 9 & 14 & 4 & 0 & 0 & 0 & 70 & 16 & 0 & 0 & 0 & 86 & 18 \\
\hline 10 & 3 & 11 & 4 & 0 & 0 & 15 & 44 & 12 & 0 & 0 & 71 & 18 \\
\hline 11 & 14 & 4 & 0 & 0 & 0 & 70 & 16 & 0 & 0 & 0 & 86 & 18 \\
\hline 12 & 9 & 9 & 0 & 0 & 0 & 45 & 36 & 0 & 0 & 0 & 81 & 18 \\
\hline 13 & 12 & 6 & 0 & 0 & 0 & 60 & 24 & 0 & 0 & 0 & 84 & 18 \\
\hline 14 & 15 & 3 & 0 & 0 & 0 & 75 & 12 & 0 & 0 & 0 & 87 & 18 \\
\hline 15 & 13 & 5 & 0 & 0 & 0 & 65 & 20 & 0 & 0 & 0 & 85 & 18 \\
\hline 16 & 12 & 6 & 0 & 0 & 0 & 60 & 24 & 0 & 0 & 0 & 84 & 18 \\
\hline 17 & 8 & 10 & 0 & 0 & 0 & 40 & 40 & 0 & 0 & 0 & 80 & 18 \\
\hline 18 & 3 & 15 & 0 & 0 & 0 & 15 & 60 & 0 & 0 & 0 & 75 & 18 \\
\hline 19 & 9 & 9 & 0 & 0 & 0 & 45 & 36 & 0 & 0 & 0 & 81 & 18 \\
\hline 20 & 5 & 13 & 0 & 0 & 0 & 25 & 52 & 0 & 0 & 0 & 77 & 18 \\
\hline 21 & 10 & 8 & 0 & 0 & 0 & 50 & 32 & 0 & 0 & 0 & 82 & 18 \\
\hline 22 & 8 & 10 & 0 & 0 & 0 & 40 & 40 & 0 & 0 & 0 & 80 & 18 \\
\hline 23 & 16 & 2 & 0 & 0 & 0 & 80 & 8 & 0 & 0 & 0 & 88 & 18 \\
\hline 24 & 8 & 9 & 1 & 0 & 0 & 40 & 36 & 3 & 0 & 0 & 79 & 18 \\
\hline 25 & 10 & 7 & 1 & 0 & 0 & 50 & 28 & 3 & 0 & 0 & 81 & 18 \\
\hline 26 & 12 & 6 & 0 & 0 & 0 & 60 & 24 & 0 & 0 & 0 & 84 & 18 \\
\hline 27 & 8 & 9 & 1 & 0 & 0 & 40 & 36 & 3 & 0 & 0 & 79 & 18 \\
\hline 28 & 12 & 6 & 0 & 0 & 0 & 60 & 24 & 0 & 0 & 0 & 84 & 18 \\
\hline 29 & 10 & 8 & 0 & 0 & 0 & 50 & 32 & 0 & 0 & 0 & 82 & 18 \\
\hline 30 & 9 & 9 & 0 & 0 & 0 & 45 & 36 & 0 & 0 & 0 & 81 & 18 \\
\hline 31 & 13 & 5 & 0 & 0 & 0 & 65 & 20 & 0 & 0 & 0 & 85 & 18 \\
\hline 32 & 13 & 5 & 0 & 0 & 0 & 65 & 20 & 0 & 0 & 0 & 85 & 18 \\
\hline 33 & 12 & 6 & 0 & 0 & 0 & 60 & 24 & 0 & 0 & 0 & 84 & 18 \\
\hline 34 & 13 & 5 & 0 & 0 & 0 & 65 & 20 & 0 & 0 & 0 & 85 & 18 \\
\hline 35 & 9 & 9 & 0 & 0 & 0 & 45 & 36 & 0 & 0 & 0 & 81 & 18 \\
\hline 36 & 8 & 8 & 2 & 0 & 0 & 40 & 32 & 6 & 0 & 0 & 78 & 18 \\
\hline 37 & 7 & 10 & 1 & 0 & 0 & 35 & 40 & 3 & 0 & 0 & 78 & 18 \\
\hline 38 & 11 & 6 & 1 & 0 & 0 & 55 & 24 & 3 & 0 & 0 & 82 & 18 \\
\hline
\end{tabular}


Yuni Hidayati | Pengaruh Metode Hafalan...

\begin{tabular}{|c|c|c|c|c|c|c|c|c|c|c|c|c|}
\hline 39 & 1 & 9 & 8 & 0 & 0 & 5 & 36 & 24 & 0 & 0 & 65 & 18 \\
\hline 40 & 1 & 15 & 2 & 0 & 0 & 5 & 60 & 6 & 0 & 0 & 71 & 18 \\
\hline 41 & 4 & 12 & 2 & 0 & 0 & 20 & 48 & 6 & 0 & 0 & 74 & 18 \\
\hline 42 & 10 & 8 & 0 & 0 & 0 & 50 & 32 & 0 & 0 & 0 & 82 & 18 \\
\hline 43 & 7 & 10 & 1 & 0 & 0 & 35 & 40 & 3 & 0 & 0 & 78 & 18 \\
\hline \multicolumn{10}{|c|}{ JUMLAH } \\
\hline
\end{tabular}

Untuk mengetahui nilai interval variabel metode hafalan AlQur'an dapat dihitung sebagai berikut :

Nilai tertinggi secara keseluruhan $43 \times 5 \times 18=3870$

Nilai terrendah secara keeluruhan $43 \times 1 \times 18=774$

$\mathrm{NJI}=$ nilai tertinggi - nilai terendah

Jumlah kriteria pertanyaan

$$
\begin{aligned}
& =\frac{3870-774}{5} \\
& =619.2 \\
& =620
\end{aligned}
$$

Sedangkan klasifikasi untuk setiap indikator adalah sebagai berikut :

Tabel 4.2

Penilaian indikator secara keseluruhan variabel $\mathrm{X}$

( Metode Hafalan Al-Qur'an)

\begin{tabular}{|c|c|}
\hline Nilai & Kriteria \\
\hline $774-1393$ & Sangat kurang \\
\hline $1394-2013$ & Kurang \\
\hline $2015-2633$ & Cukup \\
\hline $2634-3253$ & Baik \\
\hline $3254-3873$ & Sangat Baik \\
\hline
\end{tabular}

Berdasarkan hasil perhitungan mengenai tanggapan responden mengenai variabel metode hafalan Al-Qur'an, maka diperoleh nilai sebesar 3504 pada tabel di atas berada pada kisaran 
3254 - 3873. Dengan nilai tersebut maka tanggapan responden mengenai metode hafalan Al-Qur'an secara keseluruhan dapat dikategorikan sangat baik. Karna sesuai dengan indikator yaitu; 1). Ikhlas 2). Menguasai Ilmu Tajwid 3). Suara yang Keras 4). Mengulang Hafalan 5). Menjaga Kesehatan 6). Riyadhah

\section{Kecerdasan Spiritual Santri}

Data mengenai kecerdasan spiritual santri yang menjadi variabel Y (dependen) merupakan data yang diperoleh langsung dari pengisian instrument penelitian yang berbentuk skala likert yang mengamati sehari-hari tingkat kecerdasan spiritual santri dengan 18 item pernyataan. Untuk lebih jelasnya deskripsi data penelitian mengenai variabel tingkat kecerdasan spiritual santri dapat di lihat pada tabel beriikut :

\section{Tabel 4.3}

\section{Rekapitulasi Tanggapan Responden Variabel Y}

\begin{tabular}{|c|c|c|c|c|c|c|c|c|c|c|c|c|}
\hline \multicolumn{13}{|c|}{ Rekapitulasi Tanggapan Responden Tingkat Kecerdasan Santri } \\
\hline \multirow[t]{2}{*}{ Resp } & \multicolumn{5}{|c|}{ Jawaban } & \multicolumn{5}{|c|}{ Penskoran } & \multirow[t]{2}{*}{ Total } & \multirow[t]{2}{*}{$\begin{array}{c}\text { Jumlah } \\
\text { Soal }\end{array}$} \\
\hline & SS & $\mathbf{S}$ & $\mathbf{R}$ & TS & STS & 5 & 4 & 3 & 2 & 1 & & \\
\hline 1 & 14 & 4 & 0 & 0 & 0 & 70 & 16 & 0 & 0 & 0 & 86 & 18 \\
\hline 2 & 11 & 7 & 0 & 0 & 0 & 55 & 28 & 0 & 0 & 0 & 83 & 18 \\
\hline 3 & 17 & 1 & 0 & 0 & 0 & 85 & 4 & 0 & 0 & 0 & 89 & 18 \\
\hline 4 & 6 & 12 & 0 & 0 & 0 & 30 & 48 & 0 & 0 & 0 & 78 & 18 \\
\hline 5 & 9 & 9 & 0 & 0 & 0 & 45 & 36 & 0 & 0 & 0 & 81 & 18 \\
\hline 6 & 13 & 5 & 0 & 0 & 0 & 65 & 20 & 0 & 0 & 0 & 85 & 18 \\
\hline 7 & 10 & 8 & 0 & 0 & 0 & 50 & 32 & 0 & 0 & 0 & 82 & 18 \\
\hline 8 & 16 & 2 & 0 & 0 & 0 & 80 & 8 & 0 & 0 & 0 & 88 & 18 \\
\hline 9 & 0 & 17 & 1 & 0 & 0 & 0 & 68 & 3 & 0 & 0 & 71 & 18 \\
\hline 10 & 11 & 7 & 0 & 0 & 0 & 55 & 28 & 0 & 0 & 0 & 83 & 18 \\
\hline 11 & 13 & 5 & 0 & 0 & 0 & 65 & 20 & 0 & 0 & 0 & 85 & 18 \\
\hline 12 & 12 & 4 & 1 & 1 & 0 & 60 & 16 & 3 & 2 & 0 & 81 & 18 \\
\hline 13 & 15 & 3 & 0 & 0 & 0 & 75 & 12 & 0 & 0 & 0 & 87 & 18 \\
\hline 14 & 15 & 3 & 0 & 0 & 0 & 75 & 12 & 0 & 0 & 0 & 87 & 18 \\
\hline 15 & 10 & 8 & 0 & 0 & 0 & 50 & 32 & 0 & 0 & 0 & 82 & 18 \\
\hline
\end{tabular}


Yuni Hidayati | Pengaruh Metode Hafalan...

\begin{tabular}{|c|c|c|c|c|c|c|c|c|c|c|c|c|}
\hline 16 & 9 & 7 & 2 & 0 & 0 & 45 & 28 & 6 & 0 & 0 & 79 & 18 \\
\hline 17 & 7 & 11 & 0 & 0 & 0 & 35 & 44 & 0 & 0 & 0 & 79 & 18 \\
\hline 18 & 3 & 14 & 1 & 0 & 0 & 15 & 56 & 3 & 0 & 0 & 74 & 18 \\
\hline 19 & 8 & 10 & 0 & 0 & 0 & 40 & 40 & 0 & 0 & 0 & 80 & 18 \\
\hline 20 & 11 & 7 & 0 & 0 & 0 & 55 & 28 & 0 & 0 & 0 & 83 & 18 \\
\hline 21 & 5 & 12 & 1 & 0 & 0 & 25 & 48 & 3 & 0 & 0 & 76 & 18 \\
\hline 22 & 11 & 6 & 1 & 0 & 0 & 55 & 24 & 3 & 0 & 0 & 82 & 18 \\
\hline 23 & 6 & 12 & 0 & 0 & 0 & 30 & 48 & 0 & 0 & 0 & 78 & 18 \\
\hline 24 & 6 & 12 & 0 & 0 & 0 & 30 & 48 & 0 & 0 & 0 & 78 & 18 \\
\hline 25 & 16 & 2 & 0 & 0 & 0 & 80 & 8 & 0 & 0 & 0 & 88 & 18 \\
\hline 26 & 18 & 0 & 0 & 0 & 0 & 90 & 0 & 0 & 0 & 0 & 90 & 18 \\
\hline 27 & 17 & 1 & 0 & 0 & 0 & 85 & 4 & 0 & 0 & 0 & 89 & 18 \\
\hline 28 & 16 & 2 & 0 & 0 & 0 & 80 & 8 & 0 & 0 & 0 & 88 & 18 \\
\hline 29 & 15 & 3 & 0 & 0 & 0 & 75 & 12 & 0 & 0 & 0 & 87 & 18 \\
\hline 30 & 6 & 11 & 1 & 0 & 0 & 30 & 44 & 3 & 0 & 0 & 77 & 18 \\
\hline 31 & 15 & 3 & 0 & 0 & 0 & 75 & 12 & 0 & 0 & 0 & 87 & 18 \\
\hline 32 & 11 & 7 & 0 & 0 & 0 & 55 & 28 & 0 & 0 & 0 & 83 & 18 \\
\hline 33 & 8 & 10 & 0 & 0 & 0 & 40 & 40 & 0 & 0 & 0 & 80 & 18 \\
\hline 34 & 18 & 0 & 0 & 0 & 0 & 90 & 0 & 0 & 0 & 0 & 90 & 18 \\
\hline 35 & 3 & 15 & 0 & 0 & 0 & 12 & 60 & 0 & 0 & 0 & 72 & 18 \\
\hline 36 & 7 & 11 & 0 & 0 & 0 & 35 & 44 & 0 & 0 & 0 & 79 & 18 \\
\hline 37 & 15 & 2 & 1 & 0 & 0 & 75 & 8 & 3 & 0 & 0 & 86 & 18 \\
\hline 38 & 12 & 5 & 0 & 1 & 0 & 60 & 20 & 0 & 2 & 0 & 82 & 18 \\
\hline 39 & 12 & 6 & 0 & 0 & 0 & 60 & 24 & 0 & 0 & 0 & 84 & 18 \\
\hline 40 & 2 & 16 & 0 & 0 & 0 & 10 & 64 & 0 & 0 & 0 & 74 & 18 \\
\hline 41 & 2 & 16 & 0 & 0 & 0 & 10 & 64 & 0 & 0 & 0 & 74 & 18 \\
\hline 42 & 14 & 4 & 0 & 0 & 0 & 70 & 16 & 0 & 0 & 0 & 86 & 18 \\
\hline 43 & 8 & 10 & 0 & 0 & 0 & 40 & 40 & 0 & 0 & 0 & 80 & 18 \\
\hline \multicolumn{13}{|c|}{ JUMLAH } \\
\hline
\end{tabular}

Untuk mengetahui nilai interval variabel kecerdasan spiritual santri dapat dihitung sebagai berikut ;

Nilai tertinggi secara keseluruhan 43 × 5 × $18=3870$

Nilai terendah secara keseluruhan 43 × 1 x $18=774$

$\mathrm{NJI}=$ nilai tertinggi - nilai terendah

Jumlah kriteria pertanyaan 


$$
\begin{aligned}
& =\frac{3870-774}{5} \\
& =619.2=620
\end{aligned}
$$

Sedangkan klasifikasi untuk setiap indikator adalah sebagai berikut :

Tabel 4.4

Penilaian indikator secara keseluruhan variabel Y

( Tingkat Kecerdasan Spiritual )

\begin{tabular}{|c|c|}
\hline Nilai & Kriteria \\
\hline $774-1393$ & Sangat kurang \\
\hline $1394-2013$ & Kurang \\
\hline $2015-2633$ & Cukup \\
\hline $2634-3253$ & Baik \\
\hline $3254-3873$ & Sangat Baik \\
\hline
\end{tabular}

Berdasarkan hasil perhitungan mengenai tanggapan responden tentang variabel Tingkat kecerdasan spiritual santri di pondok pesantren Daarul-Anba, diperoleh nilai sebesar 3533 pada tabel di atas berada pada kisaran 3254 - 3873. Dengan nilai tersebut maka tanggapan responden mengenai tingkat kecerdasan spiritual santri secara keseluruhan dapat dikategorikan sangat baik. Karena sesuai dengan indikator yaitu ; 1). Prinsip Bintang 2). Prinsip Malaikat 3). Prinsip Kepemimpinan 4). Prinsip Pembelajaran 5). Prinsip Masa Depan 6). Prinsip Keteraturan

3. Pengaruh Metode Hafalan Al-Qur'an Terhadap Tingkat Kecerdasan Spiritual Santri di Pondok Pesantren Daarul-Anba

Setelah melakukan penelitian dan memperoleh data yang diperlukan mengenai pengaruh metode hafalan Al-Qur'an terhadap tingkat kecerdasan spiritual santri di pondok pesantren daarul-anba yang disebarkan kepada 43 responden dengan 18 item pertanyaan 
pada tiap-tiap variabel, maka dilakukan pengujian. Dalam pengujian hipotesis dilakukan serangkaian langkah-langkah uji statisik.

Untuk keperluan analisis data, penulis menggunakan program SPSS versi 21.0 dengan tujuan untuk memperoleh hasil pengujian yang akurat. Berikut ini adalah data mengenai skor metode hafalan Al-Qur'an dan tingkat kecerdasan spiritual santri di pondok pesantren daarul-anba pada 43 orang responden yang disajikan pada tabel di bawah ini :

Tabel 4.5

Rekapitulasi Skor Penilaian Variabel X dan Y

\begin{tabular}{|c|c|c|}
\hline Responden & variabel X & Variabel Y \\
\hline 1 & 89 & 86 \\
\hline 2 & 84 & 83 \\
\hline 3 & 78 & 89 \\
\hline 4 & 81 & 78 \\
\hline 5 & 90 & 81 \\
\hline 6 & 88 & 85 \\
\hline 7 & 85 & 82 \\
\hline 8 & 84 & 88 \\
\hline 9 & 86 & 71 \\
\hline 10 & 71 & 83 \\
\hline 11 & 86 & 85 \\
\hline 12 & 81 & 81 \\
\hline 13 & 84 & 87 \\
\hline 14 & 87 & 87 \\
\hline 15 & 85 & 82 \\
\hline 16 & 84 & 79 \\
\hline 17 & 80 & 79 \\
\hline 18 & 75 & 74 \\
\hline 19 & 81 & 80 \\
\hline 20 & 77 & 83 \\
\hline 21 & 82 & 76 \\
\hline 22 & 80 & 82 \\
\hline 23 & 88 & 78 \\
\hline 24 & 79 & 78 \\
\hline
\end{tabular}




\begin{tabular}{|c|c|c|}
\hline 25 & 81 & 88 \\
\hline 26 & 84 & 90 \\
\hline 27 & 79 & 89 \\
\hline 28 & 84 & 88 \\
\hline 29 & 82 & 87 \\
\hline 30 & 81 & 77 \\
\hline 31 & 85 & 87 \\
\hline 32 & 85 & 83 \\
\hline 33 & 84 & 80 \\
\hline 34 & 85 & 90 \\
\hline 35 & 81 & 72 \\
\hline 36 & 78 & 79 \\
\hline 37 & 78 & 86 \\
\hline 38 & 82 & 82 \\
\hline 39 & 65 & 84 \\
\hline 40 & 71 & 74 \\
\hline 41 & 74 & 74 \\
\hline 42 & 82 & 86 \\
\hline 43 & 78 & 80 \\
\hline JUMLAH & 3504 & 3533 \\
\hline Rata-rata & 81.4883 & 82.1627 \\
\hline Standar Deviasi & 5.04443 & 5.10933 \\
\hline
\end{tabular}

\section{Uji Prasarat Analsis}

\section{Uji Validitas}

Uji ini dilakukan dengan cara membandingkan angka $r$ hitung dan $r$ tabel, jika $r$ hitung lebih besar dari $r$ tabel maka item dikatakan valid dan sebaliknya jika $r$ hitung lebih kecil dari $r$ tabel maka item dikatakan tidak valid. $\mathbf{r}$ hitung dicari dengan menggunakan program SPSS, sedangkan $r$ tabel dicari dengan cara melihat tabel $\mathrm{r}$ dengan ketentuan $\mathrm{r}$ minimal 0,3 jika $\mathrm{r}$ tabel $<$ 0,3 maka data tersebut dikatakan tidak valid. jika $r$ tabel $>0.3$ maka data tersebut dikatakan valid. 
Tabel 4.6

Uji Validitas Variabel X

Item-Total Statistics

Berikut di bawah ini tabel hasil dari uji validitas variabel X

\begin{tabular}{|c|c|c|c|c|c|}
\hline No & $\begin{array}{c}\text { Scale Mean } \\
\text { if Item } \\
\text { Deleted }\end{array}$ & $\begin{array}{c}\text { Scale } \\
\text { Variance if } \\
\text { Item Deleted }\end{array}$ & $\begin{array}{c}\text { Corrected } \\
\text { Item-Total } \\
\text { Correlation }\end{array}$ & $\begin{array}{c}\text { Cronbach' } \\
\text { s Alpha if } \\
\text { Item } \\
\text { Deleted }\end{array}$ & $\begin{array}{c}\text { Informatio } \\
\text { n }\end{array}$ \\
\hline no.1 & 76.5349 & 24.493 & .431 & .829 & Valid \\
\hline no.2 & 76.6977 & 23.502 & .445 & .824 & Valid \\
\hline no.3 & 76.9535 & 22.760 & .414 & .825 & Valid \\
\hline no.4 & 76.9302 & 22.543 & .456 & .823 & Valid \\
\hline no.5 & 77.0000 & 23.286 & .349 & .828 & Valid \\
\hline no.6 & 77.0000 & 23.048 & .441 & .824 & Valid \\
\hline no.7 & 77.0000 & 22.810 & .493 & .821 & Valid \\
\hline no.8 & 76.9070 & 23.563 & .337 & .828 & Valid \\
\hline no.9 & 76.9767 & 23.309 & .385 & .826 & Valid \\
\hline no.10 & 76.9070 & 23.134 & .385 & .826 & Valid \\
\hline no.11 & 76.9302 & 22.828 & .443 & .823 & Valid \\
\hline no.12 & 76.9070 & 22.753 & .420 & .825 & Valid \\
\hline no.13 & 77.0930 & 22.134 & .542 & .818 & Valid \\
\hline no.14 & 77.0465 & 21.903 & .535 & .818 & Valid \\
\hline no.15 & 77.1163 & 22.439 & .448 & .823 & Valid \\
\hline no.16 & 77.1628 & 22.187 & .506 & .820 & Valid \\
\hline no.17 & 77.1163 & 23.010 & .379 & .827 & Valid \\
\hline no.18 & 77.0233 & 22.880 & .332 & .831 & Valid \\
\hline & & & & & \\
\hline
\end{tabular}

Dari tabel di atas dapat dilihat pada kolom Corrected Item-Total Correlation bahwa hasil dari uji validitas pengolahan data tersebut $>0,3$ dalam artian data yang di peroleh adalah valid.

Tabel 4.7

Uji Validitas Variabel Y 
Item-Total Statistics

\begin{tabular}{|l|r|r|r|r|c|}
\hline No. & $\begin{array}{c}\text { Scale Mean } \\
\text { if Item } \\
\text { Deleted }\end{array}$ & $\begin{array}{c}\text { Scale } \\
\text { Variance if } \\
\text { Item } \\
\text { Deleted }\end{array}$ & $\begin{array}{c}\text { Corrected } \\
\text { Item-Total } \\
\text { Correlation }\end{array}$ & $\begin{array}{c}\text { Cronbach's } \\
\text { Alpha if } \\
\text { Item } \\
\text { Deleted }\end{array}$ & $\begin{array}{c}\text { informat } \\
\text { ion }\end{array}$ \\
\hline no.1 & 60.2093 & 23.646 & .672 & .855 & Valid \\
no.2 & 60.0233 & 24.976 & .399 & .866 & Valid \\
no.3 & 60.0465 & 25.236 & .382 & .866 & Valid \\
no.4 & 60.3023 & 24.073 & .520 & .861 & Valid \\
no.5 & 60.5814 & 24.630 & .464 & .864 & Valid \\
no.6 & 60.3953 & 24.340 & .540 & .861 & Valid \\
no.7 & 60.2093 & 23.646 & .672 & .855 & Valid \\
no.8 & 60.3256 & 23.987 & .394 & .869 & Valid \\
no.9 & 60.1395 & 24.075 & .598 & .859 & Valid \\
no.10 & 60.1163 & 24.867 & .433 & .865 & Valid \\
no.11 & 60.0233 & 24.642 & .535 & .861 & Valid \\
no.12 & 60.3488 & 23.994 & .601 & .858 & Valid \\
no.13 & 60.3256 & 24.511 & .366 & .869 & Valid \\
no.14 & 60.4186 & 24.392 & .436 & .865 & Valid \\
no.15 & 60.1628 & 24.425 & .461 & .864 & Valid \\
no.16 & 59.9535 & 25.379 & .416 & .865 & Valid \\
no.17 & 60.1395 & 24.409 & .525 & .861 & Valid \\
\hline no.18 & 60.3256 & 24.558 & .428 & .865 & Valid \\
\hline
\end{tabular}

2. Uji Realibilitas

Tabel 4.8

Uji Realibilitas

\begin{tabular}{|l|l|c|c|}
\hline No & \multicolumn{1}{|c|}{ Variabel } & Skor & Kategori \\
\hline 1 & Metode Hafalan Al-Qur'an & 0,832 & Reliabel \\
\hline 2 & Kecerdasan Spiritual Santri & 0,747 & Reliabel \\
\hline
\end{tabular}

Hasil Uji Realibilitas diatas dapat dinyatakan bahwa semua variabel termasuk kategori variabel, karena skornya > 0,60 dengan demikian instrument penelitian yang digunakan masing-masing variabel pada penelitian ini dapat dinyatakan reliabel dan benar-benar sebagai alat ukur yang handal dan 
memiliki tingkat kestabilan yang tinggi, dalam arti alat ukur tersebut apabila dilakuakan secara berulang maka hasil dari pengujian instrument tersebut akan menunjukan hasil yang tepat.

\section{Uji Normalitas}

Uji normalitas bertujuan untuk menguji apakah dalam model regresi variabel bebas dan terikat, keduanya terdistribsikan secara normal atau tidak. Normalitas data dalam penelitian ini berasumsikan pada :

1) Jika nilai signifikansi $>0,05$, maka data berdistribusi normal.

2) Jika nilai signifikansi $<0,05$, maka data tidak berdistrbusi normal.

Hasil dari perhitungan uji normalitas dengan menggunakan bantuan aplikasi SPSS IBM versi 21.0 yaitu sebagai berikut :

Tabel 4.9

Uji Normalitas

One-Sample Kolmogorov-Smirnov Test

\begin{tabular}{|c|c|c|c|}
\hline & & $\begin{array}{l}\text { Metode } \\
\text { Hafalan } \\
\text { Al-Qur'an }\end{array}$ & \begin{tabular}{|l} 
Tingkat \\
Kecerdasan \\
Spiritual \\
Santri \\
\end{tabular} \\
\hline \multicolumn{2}{|l|}{$\mathrm{N}$} & 43 & 43 \\
\hline & Mean & 81.4884 & 81.8837 \\
\hline \multirow[t]{2}{*}{ Normal Parameters ${ }^{\mathrm{a}, \mathrm{b}}$} & & 5.04443 & 5.10933 \\
\hline & Deviation & & \\
\hline \multirow{3}{*}{$\begin{array}{ll}\text { Most } & \text { Extreme } \\
\text { Differences } & \end{array}$} & Absolute & .136 & .097 \\
\hline & Positive & .080 & .063 \\
\hline & Negative & -.136 & -.097 \\
\hline \multicolumn{2}{|l|}{ Kolmogorov-Smirnov Z } & .891 & .639 \\
\hline \multicolumn{2}{|l|}{ Asymp. Sig. (2-tailed) } & .405 & .808 \\
\hline
\end{tabular}

a. Test distribution is Normal.

b. Calculated from data.

Nilai signifikansi untuk Metode Hafalan Al-Qur'an 0,405 yang nilainya $>0,05$ sehingga data berdistribusi normal. Nilai 
signifikansi untuk Tingkat Kecerdasan Spiritual Santri adalah 0,808 sehingga $>0,05$ yang menunjukkan bahwa data tersebut sama berdistribusi normal.

\section{Uji Linearitas}

Uji linearitas digunakan untuk menilai apakah spesifikasi model yang digunakan sudah benar atau tidak. Dengan memanfaatkan uji linearitas ini, maka akan memperoleh informasi tentang model empiritis yang sebaiknya berbentuk linier, kuadran atau kubik.

Untuk melakukan uji linearitas ini, diperoleh hasil hitung dengan menggunakan analisis statistik yang terdapat dalam program SPSS IBM versi 21.0 sebagai berikut :

Tabel 4.10

Uji Linearitas

ANOVA Table

\begin{tabular}{|l|l|l|l|l|l|l|}
\hline \multicolumn{2}{|l|}{} & $\begin{array}{l}\text { Sum of } \\
\text { Squares }\end{array}$ & df & $\begin{array}{l}\text { Mean } \\
\text { Square }\end{array}$ & F & Sig. \\
\hline $\begin{array}{l}\text { tingkat Between } \\
\text { kecerdasan } \\
\text { spiritual * } \\
\text { metode } \\
\text { hafalan al- Within Groups } \\
\text { qur'an }\end{array}$ & $\begin{array}{l}\text { (Combined) } \\
\text { Linearity } \\
\text { Deviation } \\
\text { from } \\
\text { Linearity }\end{array}$ & 803.285 & 16 & 24.580 & .909 & .569 \\
7 & 7021 & 1 & 80.021 & 2.959 & .097 \\
\hline \multicolumn{2}{|l|}{ Total } & $\begin{array}{l}1096.41 \\
9\end{array}$ & 426 & 20.884 & .772 & .694 \\
\hline
\end{tabular}

Dari hasil pengolahan data uji linearitas, diperoleh nilai sigifikansi $=0,694>0,05$ yang artinya terdapat hubungan yang signifikan antara Metode Hafalan Al-Qur'an (X) dengan Tingkat Kecerdasan Spiritual Santri (Y).

\section{Analisis Regresi Linier Sederhana}

Analisis regresi antara Metode Hafalan Al-Qur'an (X) terhadap Tingkat Kecerdasan Spiritual Santri (Y), yang 
bertujuan untuk mengetahui pola dan mengukur pengaruh metode hafalan Al-Qur'an terhadap tingkat kecerdasan santri di pondok pesantren Daarul-Anba, Bantargedang, Kersanagara, Cibeureum kota Tasikmalaya. Berdasarkan pengolahan data hasil Angket dengan menggunakan program SPSS IBM versi 21.0 di peroleh hasil sebagai berikut :

Tabel 4.11

Analisis Regresi Linier Sederhana

\section{Coefficients $^{\mathrm{a}}$}

\begin{tabular}{|l|l|l|l|l|l|}
\hline T & \multicolumn{2}{|l|}{$\begin{array}{l}\text { Unstandardized } \\
\text { Coefficients }\end{array}$} & $\begin{array}{l}\text { Standardized } \\
\text { Coefficients }\end{array}$ & $\mathrm{t}$ & Sig. \\
\cline { 2 - 5 } & $\mathrm{B}$ & $\begin{array}{l}\text { Std. } \\
\text { Error }\end{array}$ & Beta & & \\
\hline (Constant) & 59.586 & 12.434 & & 4.792 & .000 \\
\hline $\begin{array}{l}\text { Metode } \\
\text { Hafalan Al- } \\
\text { Qur'an }\end{array}$ & .274 & .152 & .270 & 1.797 & .080 \\
\hline
\end{tabular}

a. Dependent Variable: Tingkat Kecerdasan Spiritual Santri

Dari data di atas diperoleh persamaan regresi linier sederhana untuk pengaruh metode hafalan Al-Qur'an terhadap tingkat kecerdasan spiritual santri yaitu $\mathrm{Y}=59.586+270 \mathrm{X}=$ 333.586

Dari persamaan tersebut dapat dijelaskan bahwa :

1) Variabel $X$ mempunyai arah koefisien yang bertanda positif terhadap variabel $\mathrm{Y}$.

2) Koefisien regresi $X$ sebesar 270 menyatakan bahwa setiap penambahan metode hafalan Al-Qur'an maka Tingkat Kecerdasan spiritual santri bertambah sebesar 270.

\section{Analisis koefisien korelasi}


Korelasi merupakan salah satu teknik analisis dalam statistik yang digunakan untuk mencari hubungan antara variabel yang bersifat kuantitatif. ${ }^{6}$

Tabel 4.12

Analisis koefisien korelasi

Correlations

\begin{tabular}{|l|l|r|r|}
\hline \multicolumn{2}{|l|}{} & $\begin{array}{c}\text { Metode } \\
\text { Hafalan Al- } \\
\text { Qur'an }\end{array}$ & $\begin{array}{c}\text { Tingkat } \\
\text { Kecerdasan } \\
\text { Spiritual } \\
\text { Santri }\end{array}$ \\
\hline \multirow{5}{*}{ Metode Hafalan Al-Qur'an } & Pearson & 1 & .270 \\
& Correlation & & .080 \\
& Sig. (2-tailed) & & 43 \\
& N & 43 & 1 \\
\hline \multirow{3}{*}{ Tingkat Kecerdasan } & Pearson & .270 & 43 \\
\hline
\end{tabular}

Berdasarkan hasil perhitungan koefisien korelasi linier sederhana (r) sebesar 0,270 artinya terdapat hubungan positif antara metode hafalan al-qur'an terhadap tingkat kecerdasan spiritual santri di pondok pesantren Daarul-Anba Bantargedang Cibeureum kota Tasikmalaya. Sedangkan klasifikasi untuk setiap indikator adalah sebagai berikut :

Tabel 4.13

Interpretasi nilai " $r$ "

\begin{tabular}{|c|l|}
\hline Besarnya "r" & \multicolumn{1}{|c|}{ Interprestasi } \\
\hline $0,00-0,20$ & $\begin{array}{l}\text { Antara variabel X dan Y memang terdapat korelasi, } \\
\text { akan tetapi korelasi itu sangat lemah atau rendah } \\
\text { sehingga korelasi itu diabaikan ( dianggap tidak ada }\end{array}$ \\
\hline
\end{tabular}


Yuni Hidayati | Pengaruh Metode Hafalan...

\begin{tabular}{|c|l|}
\hline Besarnya "r" & \multicolumn{1}{|c|}{ Interprestasi } \\
\hline & korelasi antara variabel X dan variabel $\mathrm{Y}$ ) \\
\hline $0,20-0,40$ & $\begin{array}{l}\text { Antara variabel } \mathrm{X} \text { dan variabael } \mathrm{Y} \text { terdapat korelasi } \\
\text { yang rendah namun cukup berarti. }\end{array}$ \\
\hline $0,40-0,70$ & $\begin{array}{l}\text { Antara variabel } \mathrm{X} \text { dan variabael } \mathrm{Y} \text { terdapat korelasi } \\
\text { yang sedang dan cukup. }\end{array}$ \\
\hline $0,70-0,90$ & $\begin{array}{l}\text { Antara variabel } \mathrm{X} \text { dan variabael Y terdapat korelasi } \\
\text { yang kuat atau tinggi. }\end{array}$ \\
\hline $0,90-1,00$ & $\begin{array}{l}\text { Antara variabel } \mathrm{X} \text { dan variabael } \mathrm{Y} \text { terdapat korelasi } \\
\text { yang sangat kuat atau sangat tinggi. }\end{array}$ \\
\hline
\end{tabular}

Sumber :

Jika diinterprestasikan, maka korelasi terebut termasuk pada korelasi lemah atau rendah karena berada diantara 0,20 0,40 sehingga dapat diartikan bahwa semakin baik metode hafalan Al-Qur'an maka semakin berpengaruh tehadap tigkat kecerdasan spiritual santri di pondok pesantren dan juga akan semakin baik dan kuat.

\section{Analisis Koefisien Determinasi}

Dengan menggunakan koefisien determinasi, dimana nilai $\mathrm{Kd}$ dapat dicari sebagai berikut :

$$
\begin{aligned}
\mathrm{Kd} & =\mathrm{r}^{2} \times 100 \% \\
\mathrm{Kd} & =(0,270)^{2} \times 100 \% \\
& =0,0729 \times 100 \% \\
& =0,0729 \\
& =7,29 \%
\end{aligned}
$$

Nilai koefisien determinasi tersebut menunjukan bahwa nilai rata-rata Tingkat kecerdasan spiritual santri di pondok pesantren Daarul-Anba sebesar 7,29\% ditentukan oleh Metode hafalan Al-Qur'an yang cukup baik. 


\section{Analiis Koefisien Non Determinasi}

Untuk mengetahui faktor-faktoir lain di luar variabel $\mathrm{X}$ yang mempengaruhi variablel $\mathrm{Y}$ dapat diketahui dengan menganalisis non determinasi sebagai berikut :

$$
\begin{aligned}
\text { KND } & =100 \%-\left(100 \% \times \mathrm{r} \mathrm{r}^{2}\right) \\
& =100 \%-\mathrm{Kd} \\
& =100 \%-7,29 \% \\
& =92.71 \%
\end{aligned}
$$

faktor- faktor lain yang mempengaruhi tingkat kecerdasan spiritual santri di Pondok Pesantren Daarul-Anba diantaranya bisa melalui Manajemen Pesantren, Pengelolaan Pembelajaran atau bahkan Metode Pengajaran yang digunakan.

\section{Pengujian Hipotesis}

Untuk menguji pengaruh Metode Hafalan Al-Qur'an terhadap Tingkat Kecerdasan Spiritual Santri di pondok pesantren Daarul-Anba Bantargedang Kota Tasikmalaya, dapat dilakukan dengan menggunakan uji hipotesis. Yang diuji dalam penelitian ini berkaitan dengan ada tidaknya pengaruh antara variabel X ( Metode Hafalan Al-Qur'an) terhadap variabel Y. (Tingkat Kecerdasan Spritual).

Tabel 4.14

Pengujian Hipotesis

\begin{tabular}{|l|l|l|l|l|l|l|}
\hline \multicolumn{2}{|l|}{ Model } & \multicolumn{2}{|l|}{\begin{tabular}{l} 
Unstandardized \\
\multicolumn{2}{|l|}{ Coefficients }
\end{tabular}} & $\begin{array}{l}\text { Standardi } \\
\text { zed Coef } \\
\text { ficients }\end{array}$ & Sig. \\
\cline { 2 - 6 } & B & $\begin{array}{l}\text { Std. } \\
\text { Error }\end{array}$ & Beta & & \\
\hline \multirow{2}{*}{1} & \begin{tabular}{l} 
(Constant) \\
\cline { 2 - 7 } \\
Metode Hafalan Al- \\
Qur'an
\end{tabular} & 59.586 & 12.434 & & 4.792 & .000 \\
\hline
\end{tabular}

a. Dependent Variable: Tingkat Kecerdasan Spiritual Santri 
Berdasarkan perhitungan dengan SPSS IBM versi 21.0 diperoleh nilai thitung sebesar 1,797 kemudian dibandingkan dengan ttabel dengan alpha $0,05, \mathrm{df}=\mathrm{N}-2=43-2=41$

Ternyata thitung $=1,797$ lebih besar dari ttabel $=1,682$ sehingga Ha diterima, yaitu terdapat korelasi atau hubungan yang cukup signifikan antara Metode Hafalan Al-Qur'an terhadap Tingkat Kecerdasan Spiritual Santri di Pondok Pesantren Daarul-Anba Bantargedang Kota Tasikmalaya dan Ho ditolak.

\section{KESIMPULAN}

1. Deskripsi tentang Metode Hafalan Al-Qur'an di Pondok pesantren Daarul-Anba Bntargedang diperoleh nilai sebesar 3504 yang berada pada kisaran 3254 - 3873. Dengan nilai tersebut maka tanggapan responden mengenai metode hafalan Al-Qur'an di pondok pesantren Daarul-Anba secara keseluruhan dapat dikategorikan sangat baik. Karna sesuai dengan indikator yaitu; 1). Ikhlas 2). Menguasai Ilmu Tajwid 3). Suara yang Keras 4). Mengulang Hafalan 5). Menjaga Kesehatan 6). Riyadhah

2. Berdasarkan hasil perhitungan mengenai tanggapan responden tentang variabel Tingkat kecerdasan spiritual santri di pondok pesantren Daarul-Anba, diperoleh nilai sebesar 3533 pada tabel di atas berada pada kisaran 3254 3873. Dengan nilai tersebut maka tanggapan responden mengenai tingkat kecerdasan spiritual santri secara keseluruhan dapat dikategorikan sangat baik. Karena sesuai dengan indikator yaitu ; 1). Prinsip Bintang 2). Prinsip Malaikat 3). Prinsip Kepemimpinan 4). Prinsip Pembelajaran 5). Prinsip Masa Depan 6). Prinsip Keteraturan.

3. Pengaruh Metode Hafalan Al-Qur'an terhadap Tingkat Kecerdasan Spiritual Santri di Pondok Pesantren DaarulAnba Bantargedang Kota Tasikmalaya dibuktikan dengan uji hipotesis sebagai berikut : 
a. Nilai koefisien determinasi tersebut mennjukkan bahwa nilai rata-rata Tingkat kecerdasan spiritual santri di pondok pesantren Daarul-Anba sebesar 7,29\% ditentukan oleh Metode hafalan Al-Qur'an yang cukup baik. Dan sisanya sebesar $92,71 \%$ di pengaruhi oleh faktor-faktor yang lain yang tidak diteliti oleh peneliti.

b. Berdasarkan perhitungan dengan Program SPSS versi 21.0 nilai thitung sebesar 1,797 kemudian dibandingkan dengan ttabel dengan alpha $0,05, \mathrm{df}=\mathrm{N}-2=43-2=41$. Ternyata thitung $=1,797$ lebih besar dari ttabel $=0,3008$ sehingga Ha diterima, yaitu terdapat korelasi atau hubungan yang signifikan antara Metode Hafalan AlQur'an terhadap Tingkat Kecerdasan Spiritual Santri di Pondok Pesantren.

\section{DAFTAR PUSTAKA}

Agustian Ary Ginanjar, Rahasia Sukses Membangun Kecerdasan Emosi dan Spiritual (ESQ),(Jakarta:Arga.2001)

Mahfud Rois, Al-Islam, Pendidikan Agama Islam, (Jakarta:Erlangga,2011)

Mujamil Qomar,(2009), Pesantren dari Transformasi Metodologi Menuju Demokratisasi Institusi penerbit Erlangga;Jakarta.

Raghib As-Sirjani dan Abdurrahman Abdul Khalik,(2013), Cara Cerdas Menghafal A-Qur'an, PT.AQWAM MEDIA PROFETIKA: Solo

Sugiyono Metode Penelitian Pendidikan(pendekatan kuantitatif, Kualitatif dan RD), (Bandung:Alfabeta, 2010)

Sudijono Anas, pengntar Statistik Pendidikan, (Jakarta: PT RajaGrapindo Persada, 2000), 